загалом цей тип навчання стояв на заваді залучення учнів до активної самостійної пізнавальної діяльності і розвитку інтелектуальних можливостей кожної особистості, оволодіння методами самостійної пізнавальної діяльності» [1, с. 99-100].

Власний педагогічний досвід дає можливість стверджувати, що схарактеризовані форми роботи активізують пізнавальну активність старшокласників, передбачають самостійний пошук знань, роботу з різними джерелами інформації, власну творчість. Все це створює умови для інтенсивного розвитку інтелектуальних здібностей розуміння, рефлексії, конструктивного мислення (проектування, програмування, комунікації).

Отже, дидактична адаптація форм, методів, прийомів i засобів самостійної пізнавальної діяльності сприяє реалізації принципу наступності в парадигмі учень старшої школи - студент вищого навчального закладу. Цікавим є підхід до проблеми зв'язку форм навчання в загальноосвітньому навчальному закладі та вищому, що дозволяє поєднувати елементи дидактики середньої та вищої освіти. Така адаптація забезпечує формування стійкого інтересу до навчання, до самоосвіти та самовдосканалення, набуття необхідних практичних умінь і навичок для організації самостійної навчальної діяльності.

Перспективою подальших досліджень у цьому напрямку $є$ розроблення та апробування дидактичної моделі організації самостійної навчальної діяльності учнів старшої школи.

\title{
Література
}

1. Кузьмінський А. І. Педагогіка / А. І. Кузьмінський, В. Л. Омеляненко. - Київ : Знання, 2007. - 447 с. 2. Куписевич Ч. Основы общей дидактики / Ч. Куписевич. - М. : Высшая школа, 1986. - 320 с. 3. Ягупов В. В. Педагогіка: [навч. посіб.] / Василь Васильович Ягупов. - Київ : Либідь, 2003. - 560 с.

УДК 373.6:51

Олександр Сахновський

\section{НАВЧАННЯ «ЗА ПРОФІЛЕМ»: УКРАЇНСЬКА ШКІЛЬНА ОСВІТА В ПОШУКУ НОВОЇ МОДЕЛІ}

Сахновський О. С. Навчання «за профілем»: українська шкільна освіта в пошуку нової моделі.

Автор висвітлює актуальні питання впровадження профільного навчання в сучасній українській школі. Розкриваються пріоритетні напрямки його організації в умовах трансформації традиційного освітнього середовища. Відзначено, що профілізація $\epsilon$ структурною перебудовою, яка стосується сукупності важливих складників шкільного життя i, стимулюючи певні позитивні процеси в освіті, посідає своє місце в їі різнорівневій системі.

Ключові слова: профільне навчання, організація, школа, освіта, індивідуалізація, самовизначення, компетентність.

Сахновский А. Е. Обучение «по профилю»: украинское школьное образование в поисках новой модели.

Автор освящяет актуальные вопросы внедрения профильного обучения в современной украинской школе. Раскрываются приоритетные направления его организации в условиях трансформации традиционной образовательной среды. Отмечено, что профилизация представляет собой серьезную структурную перестройку, которая затрагивает целый комплекс важных составляющих школьной жизни и, 
стимулируя ряд позитивних процессов в образовании, занимает свое место в её разноуровневой системе.

Ключевые слова: профильное обучение, организация, школа, образование, индивидуализация, самоопределение, компетентность.

Sakhnovskyy A. Y. Specialized education: ukrainian's school education in searching of a new model.

The author of the article covers urgent issues of provision of the specialized education in the modern school. Priority directions of its organization in transforming of the traditional educational environment are disclosed. It is noted that specialized education is a structural change which affects a range of important components of school life and has own place in its educational multi-level system by stimulating certain positive developments in education.

Key words: specialized education, organization, school, education, individualization, selfdetermination, competency.

Глобальна криза системи загальної шкільної освіти в умовах становлення постіндустріального суспільства зумовила необхідність докорінних змін у ії парадигмі й методології. Її традиційна спрямованість переважно на засвоєння й узагальнення готових знань остаточно втратила свою привабливість. Натомість актуальності набувають інтелектуальна гнучкість, винахідливість та індивідуальний стиль мислення. Нині в Україні загальновизнана необхідність зміни стратегії навчання в загальноосвітній школі, відбувається певна трансформація традиційного освітнього середовища, що зумовлює новий зміст і структуру навчання.

Даючи відповіді на виклики, що постають перед вітчизняною шкільною освітою в умовах сьогодення, очевидно, не варто шукати основну причину іiі недостатньо динамічного розвитку та певної невідповідності реаліям сучасного життя виключно у площині недостатнього фінансування. Принципово важливим є врахування й інших факторів. Зокрема, на особливу увагу заслуговує помітне зростання вимог суспільства до загальної середньої освіти. Доволі слушною видається думка російських фахівців М. Галушкіної та Т. Гурової, які зауважують, що коли соціальна рівність та прописаність соціального шляху були по факту усунені, «ми стали реально замислюватись над тим, чи зможуть наші діти, отримавши освіту, стати успішними» [1, c. 63]. Інакше кажучи, тільки в $90-\mathrm{x}$ роках XX ст. громадяни як України, так й інших держав пострадянського простору почали ставитись до шкільної освіти не лише як до елементу соціального пакету держави, а як до свого особистого ресурсу. Тому з кожним роком все з більшою наполегливістю громадськість шукає відповіді на питання: чого прагнути, чого очікувати і де шукати якісної освіти для своїх дітей?

Mema cmammi полягає у визначенні пріоритетних напрямків організації профільного навчання в умовах трансформації традиційного освітнього середовища.

Профільне навчання й оновлення старшої школи в Україні, здається, і покликані дати відповідь на більшість цих складних питань. Принаймні основна ідея профілізації полягає саме в тому, що шкільна освіта повинна стати більш індивідуалізованою, функціональною й ефективною. Відповідно до Концепції профільного навчання в старшій школі вона «створюватиме сприятливі умови для врахування індивідуальних особливостей, інтересів і потреб учнів, для формування у школярів орієнтації на той чи той вид майбутньої професійної діяльності» [4]. Справа, безумовно, актуальна й важлива, яка може дати можливість сполучити потреби суспільства і можливості школи. Водночас, здійснення запланованого організованого переходу старшої школи загальноосвітніх навчальних 
закладів до профільного навчання не залишає байдужими науковців, педагогів, батьків, учнів та є предметом гострої полеміки, суперечок і дискусій.

Вітчизняними науковцями широко досліджено різні аспекти профілізації школи. Н. Бібік, М. Бурда, Р. Вдовиченко, І. Лов’янова, О. Котова розробляли концептуальні засади особистісно зорієнтованого профільного навчання в загальноосвітніх навчальних закладах; О. Алесьєва, Е. Аршанський, А. Пінський та ін. обгрунтовували організацію допрофільного навчання в основній школі; Г. Вороніна, М. Гузик, А. Пєнтін, А. Сологуб та ін. визначили зміст навчання та організацію навчально-виховного процесу; П. Матвієнко, А. Остапенко, А. Панкевич, Н. Ткачук, Н. Шиян та ін. виявили особливості організації профільного навчання в загальноосвітніх навчальних закладах сільської місцевості тощо.

Проте уважний спостерігач за реформами помітить, що згадані вище гострі й суперечливі питання профілізації є складником принципової (хоча й менш помітної для широкої публіки) дискусії про зміну парадигм загальної середньої освіти, яка від «школи знань» переорієнтовується на «школу компетенцій». Ця дискусія не є абстрактною. У «школі знань» учня орієнтують на фундаментальні знання, грунтуючись на яких, він мав би змогу в подальшому прийняти рішення про вибір життєвого шляху. Говорячи про вітчизняну «школу знань», яка, безумовно, сягає корінням у часи Радянського Союзу, варто відзначити, що ії особливістю був поділ власне на освіту і підготовку. Як зауважує один із найавторитетніших російських фахівців 3 галузі освіти І. Фрумін, освітяни радянської школи завжди наголошували: підготовка це не наша справа; підготовка - це готувати людей до конкретної роботи, а наша справа - власне освіта [10, с. 65].

3 огляду на це, для української і російської системи освіти, поза сумнівом, характерна справжня інтелектуальність. «Візьмемо для прикладу, - продовжує Фрумін, - математику. Тут ми побачимо надзвичайно серйозну увагу до базових понять - не до прикладного аспекту питання, а до принципового... Інша яскрава ілюстрація - література. Швидше за все, у жодній країні світу не існувало такого стійкого «золотого канону»- обов'язкової програми 3 літератури і такого зв'язку 3 класичною культурою» $[10$, с. 66]. Погоджуючись 3 відомим експертом, можна без перебільшення стверджувати, що для вітчизнячної системи освіти характерний універсалізм, а ії девізом можна вважати гасло: «Знати все!» [9, с. 9].

Проте радикальні зміни, які відбуваються в сучасному світі, ведуть до становлення такого типу культури, для якої насамперед потрібна людина самостійна, критично мисляча, що вміє бачити $\mathrm{i}$ творчо розв'язувати виникаючі проблеми. У постіндустріальному суспільстві, де інформація і знання змінюються постійно, головне - це навички іiі пошуку, відбору, систематизації і застосування. У цьому контексті «знаннєва освіта», на думку багатьох фахівців з освіти, як мінімум втрачає свою ефективність, як максимум - стає зовсім недоцільною [2; 3]. Світ став занадто різноманітним, а тренд його розвитку занадто невизначеним. Отже, людина насамперед повинна не знати і вміти застосовувати конкретне знання у відомій ситуації, а розуміти розвиток об'єкта і добирати ресурси для того, щоб реагувати на нову ситуацію.

Результати авторитетних міжнародних порівняльних досліджень якості освіти загалом констатують, що вітчизняні і російські школярі білыш схильні розв'язувати задачі за готовим зразком, завчати те, що потрібно, розуміти і діяти, не кооперуючись. Однак, порівняно із західними ровесниками, значно гірше розв'язують задачі, які вимагають застосування знань у незнайомій, наближеній до реального життя ситуації. У таких сферах, як розуміння та інтерпретація текстів, пошук інформації, побудова комунікацій, використання природничо-наукових знань для пояснення реальних явищ, вони були одними 3 найслабших [10, с. 45]. 
Нині можна констатувати, що вітчизняне Міністерство освіти і науки за зразок для сучасної української школи обрало модель «школи компетенцій». Актуальність такого навчання зумовлена потребами сьогодення - створенням умов для розвитку творчої особистості, здатної навчатися впродовж усього життя. Переважна більшість педагогічної літератури на початку XXI ст. переписано на компетентнісну мову. Саме в цьому контексті знаходить своє відображення ідея впровадження профільного навчання. Адже «школа компетенцій» орієнтує на достатньо швидкий вибір профілю навчання, у межах якого відчутно скорочують викладання учням непрофільних предметів і надають достатньо широкі можливості вибору предметів для навчання за профілем, а знання чи, точніше, компетенції перевіряються за допомогою різних тестів. Отже, як зауважує С. Писарева, «на зміну традиційному принципу «вчити всіх і всьому» приходить надзвичайно важливий принцип «вчити всіх за запитами», але на основі систематичної підготовки, отриманої в основній школі» [7, с. 81].

Не буде перебільшенням твердження, що такий перехід є серйозною структурною перебудовою, що стосується цілого комплексу важливих складників шкільного життя. Адже профілізація передбачає розв'язання освітянами масштабних задач, головними 3 яких є індивідуалізація і соціалізація учнів. Проте, як показує досвід, масштабна мета на практиці часто звужується до розв'язання лише кількох задач. Учителі, які звикли до того, що їх праця і талант оцінюється насамперед за кількістю учнів, які перемогли на олімпіадах і вступили до вищих навчальних закладів, уважають пріоритетом під час реалізації реформи підготовку до вступу і «завантаження» дитини гігабайтами дат, фактів, подій, формул і реакцій.

Задля кращої підготовки учнів до вступних іспитів у ВНЗ багато вітчизняних шкіл відкривали класи з поглибленим вивченням предметів задовго до початку впровадження профілізації. Що важливо, це був ініціативний процес педагогічних колективів, які намагалися створити нові форми взаємовідносин з вищою школою. Саме 3 цих позицій нерідко оцінюється нинішня профілізація. У профільних класах вбачаються ті ж класи 3 поглибленим вивченням, але з обмеженим змістом непрофільних дисциплін.

Отже, процес профілізації сучасної школи, як відзначає І. Лов’янова, у реаліях значно «ширший і багатший за теоретичні конструкти», а отже, породжені дійсністю, виникають певні теоретичні та методичні проблеми [6]. У цьому контексті, якщо розглядати профільне навчання як розвиток здатності дитини бути самостійною i здійснювати індивідуальний вибір, гостро постає проблема свідомого вибору учнем певного профілю. Так, у положєеннях Концепції профільного навчання сформульовано припущення, що після закінчення 9-го класу всі школярі зможуть визначитися зі своїми професійними інтересами і напрямом індивідуального освітнього маршруту [4]. Однак, практично всі незалежні експерти погоджуються з тим, що культура самовизначення це зовсім не те, що виникає в дитини автоматично [5; 10, с. 47]. Зокрема, як свідчить практика, проблема вибору для українських школярів $\epsilon$ надзвичайно складною. У них нерідко розвинений патерналізм, відтак у розв'язанні проблем часто покладаються на батьків, державу, родичів тощо. Вітчизняна педагогіка все ще недостатньо налаштована на формування відповідальності в дитини, діє за інерцією і параметрами минулого.

Отже, якщо основна мета профільного навчання звучить як забезпечення реалізації індивідуальних запитів учнів, то в такому випадку постає питання: що буде 3 тими, у кого таких чітко виявлених запитів немає?

Очевидно, що впровадження профільного навчання, більше ніж інші вітчизняні освітні реформи, стикається 3 реальними інтересами школи. Певною мірою воно стимулює позитивні процеси в освіті і займає свою нішу у іiі різнорівневій системі. Водночас варто зазначити, що до 2010 р. профілізація українськіх шкіл відбувалася в 
достатньо м'яких умовах. Кожна з них мала можливість вирішувати - впроваджувати ії чи ні. Більше того, навчальний заклад мав можливість більш чи менш критично поставитися до питання про те, у яких формах уводити профільне навчання. Зовсім інша ситуація виникла при переході на «тотальну» профілізацію. Зокрема, в умовах низької наповнюваності класів у сільській місцевості адміністрація шкіл нерідко вибирає один профіль навчання, що враховує можливості закладу, але не може задовольнити індивідуальні потреби всіх школярів. Такий підхід нівелює саму ідею профільного навчання.

У цьому контексті О. Пометун підкреслює, що керівництво ЗНЗ має здійснювати вибір моделі профільної школи з урахуванням таких чинників: наявності соціального замовлення з боку учнів та їхніх батьків у підготовці з окремих предметів на рівні, що перевищує базові вимоги; орієнтації (можливості) учнів школи продовжувати освіту за обраним профілем у ВНЗ або інших навчальних закладах; забезпечення конкурентоспроможності школи тощо [8, с. 6].

3-поміж форм профільного навчання, які найбільш повно реалізують його мету й завдання, $є$ освітні округи. Вони дозволяють забезпечити доступ учнів до максимально широкого комплексу освітніх послуг шляхом ефективного використання та розвитку сильних сторін і переваг окремих освітніх установ, а також закладів культури, фізичної культури і спорту, підприємств і громадських організацій.

Під час створення у ЗНЗ профільної старшої школи важливо також здійснювати координацію з регіональними службами зайнятості та місцевими підприємствами. Нині це переважно стихійний процес.

Профільне навчання потребує застосування і впровадження нових педагогічних підходів до організації навчання, які відображають специфіку, пов'язану з інтересами, індивідуальними нахилами, різноманітними здібностями учнів старшої школи до обраного ними предмета. Це зумовлює увагу до питань підготовки вчителя, без вирішення яких реально говорити про ефективність профільного навчання неможливо. Педагог має бути готовим до проектування та реалізації профільних, базових, елективних курсів зі свого предмета. У цьому зв'язку О. Пометун підкреслює, що багато вчителів, зокрема суспільствознавства, не вважають свій рівень достатнім для повноцінної реалізації завдань профільної школи. Науковець зауважує: «Найбільші труднощі вчителі передбачають у розв'язанні таких завдань: особливості організації навчально-пізнавальної діяльності у профільній школі (більшість учителів не може чітко визначити відмінності між профільним навчанням і поглибленим вивченням предмета, особливостями викладання предметів у класах різних профілів, констатуючи лише різницю в розподілі годин та змістовому наповненні програмного матеріалу); варіативна і особиста орієнтація освітнього процесу; оволодіння методиками організації й проведення самостійної експериментально-пошукової роботи, оволодіння інтерактивними та інформаційно-комунікативними технологіями; завершення профільного самовизначення старшокласників тощо» [8, с. 8-9].

Усе вищезазначене потребує серйозної постановки питань, пов'язаних із реалізацією підготовки вчителів профільної школи і сприяння розвитку їх професійної компетентності. Загалом, для частини вітчизняних шкіл, особливо з числа сільських, існує ризик ситуації, коли учні будуть робити вигляд, що вчаться «за профілем», а вчителі - що вчать «за профілем».

Отже, введення профільного навчання $є$ серйозною структурною перебудовою старшої школи. Тому для напрацювання ефективного механізму його реалізації і наближення «до життя», по-перше, потрібне ефективне налаштування кожного елемента існуючої системи та уникнення рішень, які приймаються у вузьких часових 
горизонтах. На сучасному етапі надзвичайно важливим $\epsilon$ комплексне розв'язання питань, пов'язаних 3 фінансовим, кадровим, навчально-методичним, нормативноправовим і організаційним забезпеченням профільної школи.

По-друге, i, можливо, це найголовніший урок, який слід урахувати: у людей, для яких призначені реформи, завжди існує своя мотивація і свої засади діяльності. А тому відкрите публічне обговорення, серйозні соціологічні дослідження, незалежні експертні оцінки, неупереджений аналіз досвіду інноваційних шкіл - усе це те, без чого говорити про серйозну реформу з упровадження профільного навчання неможливо. Інакше $\epsilon$ значний ризик звести гарний задум лише до формальних зовнішніх змін.

\section{Література}

1. Галушкина М. Обновление канона / М. Галушкина, Т. Гурова, Д. Денисова // Відкритий урок. Плеяди. - 2007. - № 9-10. - С. 63-71. 2. Гендина Н. И. Образование для общества знаний и проблемы формирования информационной культуры личности [Електронний ресурс] / Н. И. Гендина // Кемерово : НИИ информационных технологий социальной сферы Кемеровского государственного университета культуры и искусств, 2004. - Режим доступу: http: // www.gpntb.ru/win /interevents/crimea2006/eng/disk/206.pdf. 3. Клепко С. Ф. Філософія освіти в європейському контексті [Електронний ресурс] / С. Ф. Клепко - Полтава: ПОІППО, 2006. - 328 с. Режим оступу: www.experts.in.ua/baza/doc/ download/klepko2.pdf. 4. Концепція профільного навчання в старшій школі, затверджена наказом МОН України від 11 вересня 2009 p. № 854 [Електронний ресурс].- Режим доступу: http: // www.osvita.ua/legislation/ Ser_osv/4827. 5. Котова О. В. Теоретичний аспект упровадження профільного навчання в сучасну освіту [Електронний ресурс]/ O. В. Котова. - Режим доступу: http://www.nbuv.gov.ua/portal/ Soc_Gum/ Nvmdpu/ 2011_7/7/11.pdf. 6. Лов'янова I. Профільна школа: історичний досвід та сучасні проблеми [Електронний ресурс] / I. Лов'янова. - Режим доступу: http: // www.nbuv.gov.ua/ portal/Soc_Gum/Gvpkhdpi/2012_24/192_197.pdf. 7. Писарева С. А. Профильное обучение как фактор обеспечения доступности образования: российское видение / С. А. Писарева. - СПб : Изд-во РГПУ им. А. И. Герцена, 2006. - 118 с. 8. Пометун О. Перехід до профільної школи: більше запитань, ніж відповідей / О. Пометун // Історія в школах України. - 2009. - № 3.- С. 5-9. 9. Терно С. Актуальні проблеми зовнішнього незалежного оцінювання та сучасної тестології / С. Терно // Історія в школах України. - 2009. - № 4. - С. 9-13. 10. Фрумин И. Организация образовательного процесса как содержание образования / И. Фрумин // Відкритий урок. Плеяди. - 2008. - № 1-2. - С. 42-49.

\section{Тетяна Сидоренко}

\section{УКРАЇНСЬКИЙ МУЗИЧНИЙ ФОЛЬКЛОР ЯК ДЖЕРЕЛО НАРОДНОЇ ПЕДАГОГІКИ}

Сидоренко Т. Д. Український музичний фольклор як джерело народної педагогіки.

У статті обгрунтовується доцільність використання на уроках музики в загальноосвітній школі українського музичного фольклору, що створює для дитини умови для залучення іï до духовних цінностей, пропонуючи в життєвих ситуаціях багаті на різноманітні переживання музичні враження.

Ключові слова: український музичний фольклор, народна педагогіка, навчальноосвітній процес, народний фольклор. 